\title{
A giant step forward: chimeric antigen receptor T-cell therapy for lymphoma
}

\author{
Houli Zhao ${ }^{1,2,3}$, Yiyun Wang ${ }^{1,2,3}$, Elaine Tan Su Yin ${ }^{1,2,3}$, Kui Zhao ${ }^{4}$, Yongxian Hu $(\bowtie)^{1,2,3}$, He Huang $(\bowtie)^{1,2,3}$ \\ ${ }^{1}$ Bone Marrow Transplantation Center, The First Affiliated Hospital, School of Medicine, Zhejiang University, Hangzhou 310000, China; \\ ${ }^{2}$ Zhejiang Province Engineering Laboratory for Stem Cell and Immunotherapy, Hangzhou 310000, China; ${ }^{3}$ Institute of Hematology, \\ Zhejiang University, Hangzhou 310000, China; ${ }^{4}$ PET-CT Center, The First Affiliated Hospital, School of Medicine, Zhejiang University, \\ Hangzhou 310000, China
}

(C) The Author(s) 2020. This article is published with open access at link.springer.com and journal.hep.com.cn

\begin{abstract}
The combination of the immunotherapy (i.e., the use of monoclonal antibodies) and the conventional chemotherapy increases the long-term survival of patients with lymphoma. However, for patients with relapsed or treatment-resistant lymphoma, a novel treatment approach is urgently needed. Chimeric antigen receptor $\mathbf{T}$ (CAR-T) cells were introduced as a treatment for these patients. Based on recent clinical data, approximately $\mathbf{5 0 \%}$ of patients with relapsed or refractory B-cell lymphoma achieved complete remission after receiving the CD19 CAR-T cell therapy. Moreover, clinical data revealed that some patients remained in remission for more than two years after the CAR-T cell therapy. Other than the CD19-targeted CAR-T, the novel target antigens, such as CD20, CD22, CD30, and CD37, which were greatly expressed on lymphoma cells, were studied under preclinical and clinical evaluations for use in the treatment of lymphoma. Nonetheless, the CAR-T therapy was usually associated with potentially lethal adverse effects, such as the cytokine release syndrome and the neurotoxicity. Therefore, optimizing the structure of CAR, creating new drugs, and combining CAR-T cell therapy with stem cell transplantation are potential solutions to increase the effectiveness of treatment and reduce the toxicity in patients with lymphoma after the CAR-T cell therapy.
\end{abstract}

Keywords chimeric antigen receptor T (CAR-T) cell; lymphoma; cytokine release syndrome (CRS); immune effector cellassociated neurotoxicity syndrome (ICANS)

\section{Introduction}

The lymphoma comprises a heterogeneous group of lymphoid neoplasms, which originate from lymphocytes, and arises in the context of immune dysregulation. Generally, the lymphoma is divided into two subtypes, namely, Hodgkin lymphomas (HL) and non-Hodgkin lymphomas (NHL) in accordance with the morphology of tumor cells. The HL is characterized using the ReedSternberg cells, which are derived from B cells [1]. The NHL is derived from diverse cell types, including B, T, or natural killer (NK) cells. In 2019, newly diagnosed HL and NHL account for $0.46 \%$ and $4.21 \%$ of cases, respectively, in the United States [2]. In China, the incidence rate of

Received December 3, 2019; accepted June 3, 2020

Correspondence: He Huang, huanghe@zju.edu.cn;

Yongxian Hu, huyongxian2000@aliyun.com malignant lymphoma is $6.68 / 100000$ [3]. Furthermore, with the aid of a conventional first-line chemotherapy regimen $(A B V D)$, the 5-year overall survival (OS) rate reaches $73 \%$ in patients with HL after $6-8$ courses of treatment [4]. Moreover, $90.1 \%$ of young patients (aged 18 to 60 years) with good prognostic factors and $43.5 \%$ of elderly patients (aged 60 to 80 years) with newly diagnosed diffuse large $\mathrm{B}$ cell lymphoma (DLBCL) can obtain a long-term survival of 6 and 10 years after $6-8$ courses of first-line chemotherapy, respectively $[5,6]$. However, $25 \%$ of patients with HL and $50 \%$ of patients with DLBCL fail to respond or relapse after the administration of the first-line chemotherapy. The majority of patients with relapsed or refractory $(\mathrm{R} / \mathrm{R})$ lymphoma eventually die due to the disease progression.

The conventional chemotherapy is proven useful in treating patients with lymphoma, but the addition of rituximab to the conventional chemotherapy regimen has increased the long-term survival by $20 \%$ and has the 
potential to cure about half of the patients with DLBCL $[5,6]$. About $85 \%-90 \%$ of NHL is derived from B cells [7], and the CD20 antigen presents on the surface of lymphoma cells. The rituximab is a milestone immunotherapy for cancer, representing the first monoclonal antibody able to target tumor cells. The rituximab binds with the CD20 on B lymphoma cells and activates antibody-dependent cellmediated cytotoxicity to kill tumor cells. In short, rather than eliminating rapidly dividing cells by using cytotoxic drugs, the aim of immunotherapy is to utilize our own immune system for the elimination of cancerous cells from the body.

Recently, the chimeric antigen receptor $\mathrm{T}(\mathrm{CAR}-\mathrm{T})$ cell, a genetically engineered immune cell product, has made remarkable progress in the treatment of hematological malignancies. The complete remission $(\mathrm{CR})$ rate of $\mathrm{R} / \mathrm{R}$ acute lymphocyte leukemia (ALL) and DLBCL can reach $90 \%[8,9]$ and $50 \%$ [10-12], respectively, by using the CD19 CAR-T cell therapy. Given their effectiveness in combating hematological malignancies, two commercial CD19-targeted CAR-T cell products are approved by the Food and Drug Administration (FDA) in 2017. As of November 2019, 887 CAR-T therapy-associated clinical trials are registered at ClinicalTrial.gov, and 268 trials are for lymphoma. Since then, the CAR-T therapy has become a popular topic in scientific research and clinical applications. In this study, we review the most recent data on CAR-T cell therapy and document the progress of research and clinical trials using this therapy.

\section{Chimeric antigen receptors (CARs)}

CARs are genetically engineered transmembrane protein that can recognize specific tumor antigens and activate immune effector cells. CAR structures are made up of antigen-recognizing, transmembrane, costimulatory, and $\mathrm{T}$ cell-activating domains. The antigen-recognizing domain is frequently derived from a single-chain variable fragment $(\mathrm{scFv})$ region, which can bind to a specific tumor antigen (Fig. 1B). The antigen-recognizing domain is fused to intracellular domains (including the costimulatory and $\mathrm{T}$ cell activation domains) via a transmembrane domain mainly derived from CD8 $\alpha$ or CD28. Researchers have designed different antigen-recognizing domains in accordance with specific tumor antigens to target different types of tumor cells. Until now, the FMC63 has been the most widely used CD19-specific monoclonal antibody in CAR$\mathrm{T}$ cells and targets CD19-positive B cell malignancies. Notably, the only two FDA-approved CAR-T cell products are based on FMC63 [11,12]. Additionally, costimulatory domains, such as CD28 and 4-1BB, have replaced antigenpresenting cells (APC) in providing second signal in the $\mathrm{T}$ cell activation signaling pathway, with the $T$ cell activation domain $\mathrm{CD} 3 \zeta$ providing the first signal in the $\mathrm{T}$ cell activation signaling pathway. When CARs bind to specific tumor antigens, the intracellular domain provides dual signals to activate CAR-T cells, leading to a tumor-killing effect and the proliferation of CAR-T cells [13].

\section{Generation of CAR-T cells}

The first attempts to generate a chimeric $\mathrm{T}$ cell receptor (TCR) composed of the TCR constant region and the Vregion domain derived from the immunoglobulin are performed in the late 1980s [14,15]. In 1993, Eshhar et al. have developed the first-generation CAR, consisting of the $\mathrm{scFv}$ and the $\mathrm{CD} 3 \zeta$ to overcome the low efficiency of single cell transduction with two separate retroviral vectors
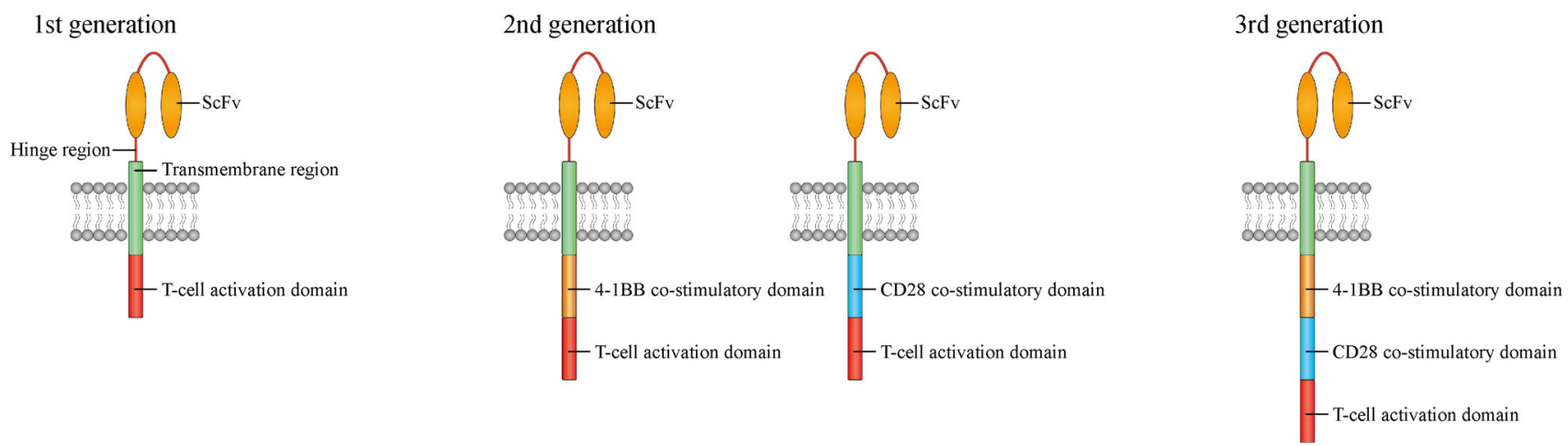

Fig. 1 Generation of CAR structures. (A) First-generation CARs contain antigen-recognizing (scFv), transmembrane, and $\mathrm{T}$ cell activation (CD3 $)$ ) domains. (B) Second-generation CARs, to which the costimulatory domains (CD28 or 4-1BB) are added with respect to the first-generation CAR, show high levels of antitumor activity. (C) Third-generation CARs include two costimulatory domains (CD28 and 4-1BB). 
[16] (Fig. 1A). However, the first-generation CAR-T cells have failed to eliminate NALM-6 tumor cells (human preB ALL cell line) in vivo $[17,18]$. Subsequently, Sadelain et al. and Campana et al. have introduced the costimulatory domains CD28 or 4-1BB into the first generation of CAR-T cells (Fig. 1B) $[18,19]$. With the addition of the costimulatory domain into the CARs, this second generation of CAR-T cells show high treatment efficacy in B cell hematological malignancies. In 2010, Rosenberg et al. have reported the treatment of a patient with advanced follicular lymphoma (FL) through the CAR-T cellular therapy. Astonishingly, this patient has obtained partial remission (PR) status for 32 weeks [20] and is the first patient with lymphoma who has been treated successfully with the CAR-T therapy. Costimulatory domains (e.g., CD28, 4-1BB, and OX40) are introduced to the third generation of CAR-T cells, and the preclinical data actually show that third-generation CARs have higher cytolytic efficacy than second-generation CARs (Fig. 1C) [21-28]. For instance, Till et al. have reported that a patient with FL and two patients with mantle cell lymphoma (MCL) have received anti-CD20 CAR-T cells containing CD28 and 4$1 \mathrm{BB}$ costimulatory domains and achieved objected response (OR) [29]. At present, many researchers are focused on designing effective and safe CAR-T cells via the addition of genes encoding cytokines [30], costimulatory ligands [31], a "safety switch" [32,33], or universal CAR [34-38].

\section{Process of the CAR-T cell therapy in clinics}

First, lymphocytes are collected from patients or donors via the leukapheresis. T cells are harvested and activated by antibody-coated beads. Usually, the $C A R$ gene is transferred into $\mathrm{T}$ cells via the transgenic technology or the electroporation [39-41] by lentivirus $[8,11]$ or retrovirus [12]. CAR-T cells are sufficiently expanded ex vivo for clinical use. Generally, patients receive the lymphodepleting chemotherapy (fludarabine and cyclophosphamide) before the CAR-T cell infusion (Fig. 2). Compared with administering cyclophosphamide alone, the combined lymphodepleting regimen of fludarabine and cyclophosphamide can effectively increase the expansion of CAR-T cells [42]. The lymphocyte depletion is a crucial step in establishing a favorable cytokine profile, eliminating immunosuppressor cells, and destroying the tumor microenvironment (TME) for improved CAR-T expansion in vivo [43-45]. Until now, only two CD19-targeted CAR-T cell products, namely, tisagenlecleucel and axicabtagene ciloleucel, have been approved worldwide by respective regulatory state health departments. However, no available commercial CAR-T cell product exists for HL and NHL derived from NK and T cells. The discovery of a new tumor-specific antigen is indispensable to broaden CAR-T therapy indications in different types of lymphoma and other solid tumors, such as anti-CD30 CAR-T cells for HL. The CAR-T therapy has shown an incredibly high CR

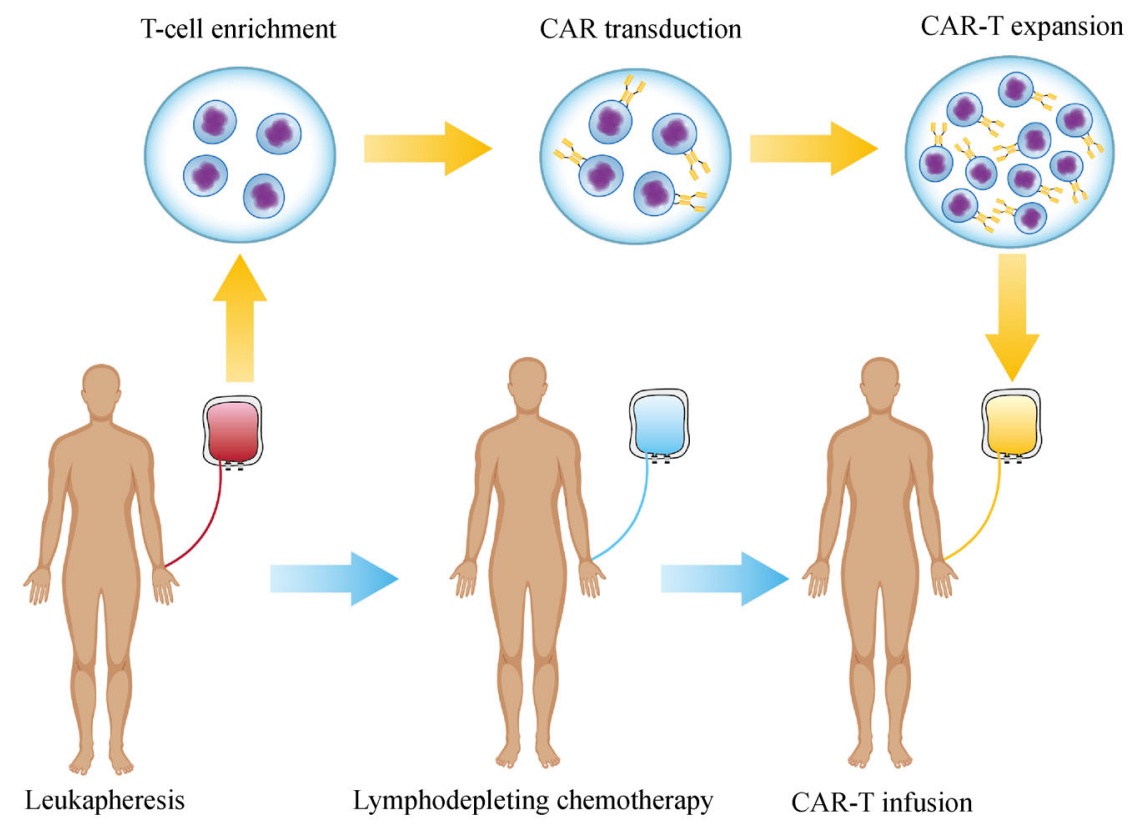

Fig. 2 Process of CAR-T cell therapy in clinics. Lymphocytes were collected from patients or donors via the leukapheresis. After T cell enrichment and activation, the CAR gene was transduced into T cells. The CAR-T cells were expanded adequately ex vivo for clinical use. Patients normally received the lymphodepleting chemotherapy prior to the CAR-T cell infusion. 
rate (about $90 \%$ ) in R/R ALL, but a CR rate of only $50 \%$ in the $\mathrm{R} / \mathrm{R}$ large $\mathrm{B}$ cell lymphoma. This phenomenon is likely to be because of the presence of the TME that limits the infiltration and the expansion of CAR-T cells in lymphoma tissues. However, many new solutions, such as the modification of the CAR structure, the combination of novel medications, and the optimization of treatment strategies (bridging CAR-T to allogenic hematopoietic stem cell transplantation (HSCT)) have been proposed to improve the remission rate and prolong the survival period in preclinical and clinical studies. Thus, in this article, we will review the clinical progression of the CAR-T cellular therapy associated with lymphoma.

\section{Data of commercialized CAR-T cell products from clinical trials}

\section{Tisagenlecleucel: JULIET clinical trial}

The tisagenlecleucel utilizes the FMC63, 4-1BB, and $\mathrm{CD} 3 \zeta$ as antigen-recognizing, costimulatory, and $\mathrm{T}$ cellactivating domains, respectively. The tisagenlecleucel is generated via lentivirus transgenic methods and approved by the FDA for the treatment of R/R ALL and B-NHL. In the JULIET clinical trial (NCT02445248), a single-group, open-label, multicenter, international phase 2 study for tisagenlecleucel in R/R DLBCL, 93 adult patients have received the tisagenlecleucel infusion at a median dose of $3 \times 10^{8}$ CAR-T cells after the lymphodepleting conditioning regimen. The best objective response rate is $52 \%(40 \%$ $\mathrm{CR}$ rate and $12 \% \mathrm{PR}$ rate) without any treatment-related mortality (TRM). In the median follow-up period of 14 months, the median OS and 12-month OS rate among patients who received an infusion is 12 months and $49 \%$, respectively. The 12-month progression-free survival (PFS) rate is estimated at $90 \%$ and the median PFS has not been reached among the patients who show a complete response (CR) at three months. For patients with a durable response, the $C A R$ gene can be detected for up to two years [11].

\section{Axicabtagene ciloleucel: ZUMA-1 clinical trial}

The axicabtagene ciloleucel, the first commercialized CAR-T cell product for R/R B-NHL, is composed of FMC63, $\mathrm{CD} 28$, and $\mathrm{CD} 3 \zeta$ via retrovirus transgenic methods. In the ZUMA-1 clinical trial, a multicentered phase 2 clinical study is conducted for the axicabtagene ciloleucel for the treatment of $\mathrm{R} / \mathrm{R}$ DLBCL, primary mediastinal B cell lymphoma, and transformed FL. Among 108 patients who have received the axicabtagene ciloleucel treatment, $82 \%$ have achieved OR, and $54 \%$ have achieved CR. Two cases have TRM. Subsequently, 101 patients are assessed for survival analysis and followed up for a median of 27.1 months. For patients who have achieved CR, PR, and stable disease (SD) at 3 months, the estimated PFS rates at 24 months are $72 \%, 75 \%$, and $22 \%$, respectively. The median OS is not reached, whereas the OS rate at 24 months is estimated at $50.5 \%$. A long PFS is associated with a high peak concentration of CAR-T cells and a great area under curve of CAR-T cell concentration within 28 days after infusion. By 24 months, the $C A R$ gene-marked cells are detected in 21 out of $32(66 \%)$ ongoing response patients [12].

Commercialized CAR-T cell products display high efficacy in eradicating lymphoma and achieving longterm persistence in vivo. Except the transgenic vector, the main difference between the tisagenlecleucel and the axicabtagene ciloleucel is the costimulatory domain, which is $4-1 \mathrm{BB}$ and $\mathrm{CD} 28$, respectively. The CD28 is a member of the immunoglobulin family of costimulatory receptors and regulates the IL-2 production and enhances the survival and the differentiation of $\mathrm{T}$ cells [46]. The 41BB (CD137), a member of the tumor necrosis factor (TNF) receptor superfamily, upregulates antiapoptotic molecules and cytokines, enhances the effector cell's function, and helps in the proliferation of memory $\mathrm{T}$ cells [47]. In a xenograft model study conducted by Carpenito et al., CD28- and 4-1BB-based CAR-T cells show the same antitumor activity, but the 4-1BB-based CAR has performed better in enhancing the persistence of T cells in vivo compared with the CD28-based CAR [24]. In addition, CAR-T cells with CD28 and 4-1BB costimulatory domains regulate different metabolism pathways. The CD28-based CAR-T cells yield a higher proportion of effector memory $\mathrm{T}$ cells and rely more on anaerobic glycolysis than 4-1BB based CAR-T cells do to fulfill the metabolic demand of the effector cell proliferation in the rapid metabolic pathway. By contrast, the 4-1BB-based CAR-T cells promote the outgrowth of central memory $\mathrm{T}$ cells, depend more on fatty acid oxidation than CD28 based CAR-T cells do, and enhance mitochondrial biogenesis with long-term persistence [48].

\section{Various types of CAR-T targeting antigens for lymphoma}

\section{Anti-CD20 CAR-T}

Undeniably, the CD20 is a classical immunotherapy target antigen for lymphoma because the CD20 is greatly expressed on B cells. For instance, rituximab, the monoclonal antibody against CD20, is a milestone immunotherapy and the first-line therapy for most of the B-NHL. Preclinical studies have found that anti-CD20 CAR-T cells show high levels of antitumor activity in vitro [49] and in vivo [50]. The CD20 antibody is widely used for B-NHL patients but may be a great challenge for 
patients with $\mathrm{R} / \mathrm{R}$ lymphoma who have previously undergone the CD20-targeting immunotherapy.

Han et al. have conducted a single-center phase I/IIa clinical trial to assess the efficacy and the safety of antiCD20 CAR-T for patients with R/R B-NHL. A total of 14 patients with $\mathrm{R} / \mathrm{R} \mathrm{CD} 20^{+}$DLBCL and 3 patients with $\mathrm{CD} 20^{+}$indolent lymphoma are recruited into this study. Each patient has received the anti-CD20 CAR-T cell infusion at a median dose of $5 \times 10^{6}-15 \times 10^{6}$ per kg. Prior to the anti-CD20 CAR-T cell infusion, 17 patients have received the rituximab treatment but experience disease progression. In this study, 8 and 6 out of 17 patients have achieved CR and PR, respectively. The best overall OR and CR rates are $82 \%$ and $47 \%$, respectively. At a median follow-up period of 20 months, the median PFS and the estimated 2-year PFS rate in 12 eligible patients for survival analysis with response are 10 months and $41.7 \%$, respectively [51].

\section{Anti-CD22 CAR-T}

Similar to the CD19, the CD22 is restrictedly expressed on the surface of $B$ cells and has shown promising antitumor activity in preclinical trials [52]. However, clinical data on the use of anti-CD22 CAR-T for the treatment of lymphoma have not been published up until now. In a clinical trial conducted by Shah et al. (NCT02315612), patients with R/R CD $22^{+}$ALL and R/R CD $22^{+}$lymphoma are enrolled. According to their published data, a 14-year old patient with refractory DLBCL who has received the anti-CD22 CAR-T cell therapy prior to the anti-CD19 CAR-T treatment has achieved SD [53]. Moreover, 21 patients with $\mathrm{R} / \mathrm{R}$ ALL, including 15 patients who have previously received the anti-CD19 CAR-T cellular therapy, have received a median dose of $1 \times 10^{6}$ per kg anti-CD22 CAR-T cell infusion. Twelve out of $21(57 \%)$ patients have achieved CR. Among the 12 patients who have achieved $\mathrm{CR}$, three patients have maintained ongoing remission at 21,9 , and 6 months after the anti-CD22 CAR-T infusion, but eight patients have relapsed at a median of 6 months after receiving the anti-CD22 CAR-T infusion. Furthermore, a patient has died of sepsis immediately after recovering from the cytokine release syndrome (CRS) and bone marrow suppression [54]. Until now, 11 anti-CD22 CAR-T cell therapy clinical trials for lymphoma are registered at clinicaltrial.gov.

\section{Anti-CD30 CAR-T}

The CD30, a transmembrane receptor and a member of the TNF receptor superfamily, is universally expressed on the surface of HL, anaplastic large cell lymphoma (ALCL), and lymphomatoid papulosis cells. The CD30 is also expressed on the surface of other lymphomas derived from $\mathrm{B}$ or T cells, such as DLBCL, primary mediastinal B cell lymphoma, mycoses fungoides, peripheral $\mathrm{T}$ cell lymphoma, and adult $\mathrm{T}$ cell leukemia/lymphoma [55-58]. The CD30 is an ideal target antigen because it is restrictedly expressed on tumor cells and on a small subset of lymphocytes [59], which may lead to a controllable risk of on-target off-tumor toxicity. In a preclinical study, antiCD30 CAR-T cells exhibit a powerful tumor-killing effect in in vitro and in vivo settings [60]. A phase 1 dose escalation clinical trial is conducted on 7 patients with $R / R$ $\mathrm{HL}$ and 2 patients with R/R ALCL. Patients have received a median dose of $0.2 \times 10^{8}-2 \times 10^{8}$ per $\mathrm{m}^{2}$ CAR-T cells without a lymphodepleting conditioning regimen. As a result, 3 of 5 patients, including one R/R ALCL patient who has received a dose of $2 \times 10^{8}$ per $\mathrm{m}^{2}$ CAR-T cells, have successfully achieved CR. The CR status of the patients with ALCL is maintained for nine months after four courses of the anti-CD30 CAR-T cell infusion. Moreover, two other patients with HL have remained CR for over 24 and 36 months. Patients treated with low doses have not achieved OR [61]. In another open-label phase 1 clinical trial, 17 patients with R/R HL and 1 patient with $\mathrm{R} / \mathrm{R}$ ALCL are enrolled. All patients have received a dose of $1 \times 10^{7}-3 \times 10^{7}$ per kg anti-CD30 CAR-T cells. In this trial, seven patients have achieved PR, and six patients have achieved SD with an OR rate of 39\%. With a followup of 3-14 months, the median PFS obtained is 6 months [62]. In these two early-phase clinical trials, anti-CD30 CAR-T cells display promising levels of antitumor activity for the $\mathrm{CD} 30^{+}$lymphoma.

\section{Anti-CD37 CAR-T}

The CD37, a cell surface glycoprotein belonging to the transmembrane 4 superfamily, is expressed in most B cell lymphomas and some types of $\mathrm{T}$ cell lymphoma, including DLBCL, FL, MCL, Burkitt's lymphoma (BL), chronic lymphocytic leukemia/small lymphocytic lymphoma (CLL/SLL), cutaneous T cell lymphoma, and peripheral $\mathrm{T}$ cell lymphoma $[63,64]$. Recently, Maus et al. and Wälchli et al. have constructed anti-CD37 CAR-T cells successfully and reported their efficiency in eradicating the B cell lymphoma in vitro and in vivo, including patientderived xenograft model $[65,66]$. Furthermore, Wälchli et al. have found that the anti-CD37 CAR-expressing B cell does not prevent the killing capacity of the anti-CD37 CAR-T, which may show superior safety by avoiding the risk of CD19 relapse due to accidental CAR transduction on patient B cells [66,67]. A phase 1 clinical trial of antiCD37 CAR T cells is expected to start in February 2020 (NCT04136275).

\section{Anti-Igк CAR-T}

As a component of membrane immunoglobulin, the $\kappa$ or the $\lambda$ light chain is expressed on the surface of mature B 
lymphocyte and neoplastic counterparts, including BL, DLBCL, FL, MCL, hairy cell leukemia, marginal zone B cell lymphoma, prolymphocytic leukemia, and lymphoplasmacytic lymphoma (LPL). The CLL/SLL is also derived from mature B lymphocytes, but the expression of surface light chains on CLL/SLL cells remains limited, which is most likely due to the deletion of the $\mathrm{B}$ cell receptor complex that contains immunoglobulin, CD79a, and CD79b. In addition to immature lymphocytes, also known as lymphoblasts, the thymic B and the plasma cells lack the surface expression of the light chain and their neoplastic counterparts, including B lymphoblastic leukemia/lymphoma, primary mediastinal B cell lymphoma, and plasma cell disorders $[68,69]$. Considering that each lymphocyte expresses either the $\kappa$ or the $\lambda$ light chain but not both, anti- $\kappa$ or anti- $\lambda$ CAR-T cells are able to eradicate lymphoid malignancies and preserve part of the mature B lymphocyte to prevent the incidence of hypogammaglobulinemia. Dotti et al. have first constructed anti- $\kappa$ CAR-T cells with CD28 costimulatory domain and proven their efficiency and safety in a preclinical study [70]. Dotti et al. have conducted a phase 1 clinical trial to evaluate the efficiency and the safety of anti- $\kappa$ CAR-T and recruited 9 patients with NHL (including 2, 2, 2, 2, and 1 patients with LPL, transformed FL, DLBCL, CLL/SLL, and MCL, respectively) and 7 patients with MM. Patients without lymphopenia have received the cyclophosphamide conditioning followed by anti- $\kappa$ CAR-T infusion. Of 16 patients, 2 patients with transformed FL and 1 patient with LPL have achieved CR and PR, respectively, and 1 patient with CLL/SLL and 4 patients with MM have achieved SD. In this study, because most patients of NHL have the B cell aplasia and the polyclonal hypogammaglobulinemia at the baseline, the potential advantage of targeting the $\kappa$ light chain and avoiding hypogammaglobulinemia requires further investigation [71].

\section{Toxicity of the CAR-T cell therapy}

\section{CRS}

The CRS is the most prominent adverse effect after the CAR-T infusion. Clinically, the CRS is markedly characterized by fever, hypoxemia, hypotension, tachycardia, coagulation dysfunction, and vital organ dysfunction. Furthermore, in laboratory findings, the CRS is marked by elevated cytokine levels, including IL-1, IL-2, IL-6, and IFN- $\gamma$. When CAR-T cells recognize tumor-specific antigens, they release IL-2, soluble IL-2R $\alpha$, IFN- $\gamma$, IL-6, soluble IL-6R, and GM-CSF and activate the mononuclear phagocytic system. APCs, which are macrophages, then secrete abundant levels of IL-1RA, IL-6, IL-8, IL-10, soluble IL-6R, IFN- $\alpha$, CXCL9, CXCL10, CCL3, and
CCL4. A high baseline disease burden and elevated clinical biomarkers, such as CRP and ferritin, are associated with severe CRS [72-77]. However, specific biomarkers to measure the severity of CRS are still not available. Therefore, until now, the management according to the CRS grading is based on the initial criteria, consisting of a combination of several clinical symptoms proposed by Lee et al. [78]. Besides, other clinical centers, such as the MD Anderson Cancer Center, Memorial Sloan Kettering Cancer Center, and University of Pennsylvania, have suggested their own CRS grading system $[77,79,80]$. The American Society for Transplantation and Cellular Therapy (ASTCT) has assigned experts from different clinical centers to agree on a set of consensual criteria for the CRS grading for the evaluation of different CAR-T cell toxicity in various clinical centers [81].

The CRS requires careful surveillance and experienced supportive care, including nonsteroidal anti-inflammatory drugs for fever, intravenous hydration, vasopressor for hypotension, and supplemental oxygen for hypoxia. Furthermore, the IL-6 receptor antagonist, tocilizumab, is prescribed for the treatment of moderate or severe CRS. However, no concrete evidence for the prophylactic or preemptive use of tocilizumab has been found because its effect on the $\mathrm{T}$ cell expansion and persistence remains unknown. For the treatment of the CRS refractory to symptomatic management and tocilizumab, steroids are strongly suggested, even though their lymphotoxicity may have a negative effect on CAR-T cells. Other cytokinemodulating agents, such as IL-6 antibody (siltuximab) [82], IL-1 receptor antagonist (anakinra) [73], and GMCSF antibody (lenzilumab) [83] are also under preclinical and clinical evaluations. Plasmapheresis is another potential modality for the CRS management that allows the direct elimination of excessive cytokines [84].

Until today, infection and CRS are difficult to differentiate on the basis of subjective symptoms and objective evidence. Therefore, after receiving the CAR-T treatment, every febrile patient should undergo the broadspectrum antibiotic therapy immediately. Moreover, CAR$\mathrm{T}$ patients commonly experience pancytopenia [85]. However, the mechanism of the pancytopenia after the CAR-T infusion remains unclear and may be related to the myelosuppressive effect of the lymphodepleting chemotherapy and the interaction of CAR-T cells with immature B cell precursors in the bone marrow. Patients with a prognosis complicated with CRS and pancytopenia require G-CSF and transfusion support [86].

\section{Immune effector cell-associated neurotoxicity syndrome (ICANS)}

The neurotoxicity related to the CAR-T therapy is once termed the CAR-related encephalopathy syndrome (CRES). With an increasing number of CRES-like 
neurotoxicity cases reported in clinical trials that use blinatumomab (a bispecific $\mathrm{T}$ cell engager (BiTE) antibody) [87], the term CRES is no longer suitable for various immunotherapies, including BiTE, other engineered $\mathrm{T}$ cells, and checkpoint inhibitors. Experts from ASTCT have unified the neurotoxicity grading system related to immunotherapy and proposed the term "immune effector cell-associated neurotoxicity syndrome" to pertain to the adverse events occurring after immunotherapy.

The ICANS is an adverse event characterized by a pathologic process involving the central nervous system (CNS) after immunotherapy, including the CAR-T cell therapy. The ICANS can be manifested as decreased attention, changes in mental state, confusion, disorientation, hallucination, aphasia, ataxia, delirium, coma, encephalopathy, and cerebral edema $[88,89]$. The ICANS is a life-threatening side effect and limits the deployment of the CAR-T treatment. The JCAR015, a commercialized CAR-T therapy that is once pending approval from FDA, is withdrawn from phase 2 clinical trials soon after five cases of fatal ICANS are reported. In this retrospective analysis, the early rapid expansion and activation of JCAR015 with a CD19-recognizing, a CD28 costimulatory, and a $\mathrm{CD} 3 \zeta$-activating domains with high levels of cytokines may be responsible for the lethal ICANS [90]. The ICANS may be related to cerebral microangiopathy and the CNS infiltration of targeted cells. A lymphodepleting condition regimen and a large quantity of inflammatory cytokines can lead to the damage of microvessels in CNS, which can eventually lead to the disruption of the bloodbrain barrier (BBB).

Several clinical trials have demonstrated that CAR-T cells are able to penetrate the BBB and eliminate targeted cells in the CNS. The presence of severe ICANS is also correlated to severe CRS [91-94]. When CAR-T cells recognize CNS-infiltrating targeted cells, such as lymphoma and leukemic cells, through the disrupted BBB, CAR-T cells and bystander immune cells release cytokines and chemokines to recruit a large number of CAR-T cells and other immune cells to the site, thus inducing a cascade reaction. With high levels of cytokines, chemokines, and immune cells, a focalized cytokine storm in the CNS develops.

As mentioned previously, an intensive lymphodepleting condition regimen, prior intrathecal chemotherapy, and CNS infiltration are potential high-risk factors for the occurrence of ICANS. Nonetheless, as a type of monoclonal antibody, the tocilizumab is unlikely to penetrate the BBB to inhibit cytokine storms in the CNS. Therefore, despite the high risk of lymphotoxicity, the dexamethasone is commonly used for severe ICANS due to its ability to penetrate the CNS and BBB. Locke et al. have found that the prophylactic use of tocilizumab in 31 patients with $R / R$ NHL receiving axicabtagene ciloleucel results in a low incidence of severe CRS but not ICANS. These data provide preliminary evidence that the prophylactic or the preemptive use of tocilizumab may not benefit the incidence of severe ICANS [95].

\section{Localized CRS and tumor lysis syndrome}

Lymphoma involves lymph nodes, bone marrow, CNS, skin, gastrointestinal tract, cardiovascular system, respiratory tracts, liver, spleen, urinary system, and other vital organs. During the antitumor activity of CAR-T cell, these cells tend to recruit bystander immune cells and induce an inflammatory cascade reaction at the tumor site. As a result, the tumor tissues and the nearby tissues become swollen. In some cases, when the lymphoma is adjacent to the respiratory tracts, veins, gastrointestinal tracts, liver, or urinary system, these tissues may swell after the infusion of CAR-T cells and may compress the corresponding tracts or cavities, thereby causing dyspnea, venous reflux disorder, ileus, jaundice, back pain, and oliguria [96]. Furthermore, if the tumor cells invade a hollow organ thoroughly, perforation and bleeding may occur [97]. As mentioned previously, the pancytopenia commonly occurs after the CAR-T cell infusion. Furthermore, if the prognosis of a patient with perforation or bleeding is complicated by the pancytopenia, this patient is likely to die due to infection or severe bleeding. Physical evaluations using whole-body PET-CT scans, brain MRIs, or lumbar punctures are essential to identify the lymphoma involvement sites before the CAR-T treatment to prevent unnecessary adverse events.

\section{B cell aplasia and hypogammaglobulinemia}

CAR-T cells eradicate neoplastic cells and normal cells with target expression on surface, known as the on-target off-tumor effect. The B cell aplasia is a specific manifestation of the on-target off-tumor effect for CAR$T$ cells targeting the pan-B antigen. As progenitors of plasma cells, once B cells are eliminated, the regeneration of plasma cells is interrupted followed by the dysfunction of immunoglobulin production, leading to hypogammaglobulinemia [98]. As a consequence of hypogammaglobulinemia, patients may be exposed to infection for a long time after the CAR-T therapy. The intravenous immunoglobulin can be used to correct hypogammaglobulinemia and prevent opportunistic infections. Limited evidence has shown that some $\mathrm{CD} 19^{-}$long-lived plasma cells are able to evade the CAR-T cell attack and persist in secreting antibodies in a B cell-independent manner [99]. However, even if the pre-existing humoral immunity is preserved after the anti-CD19 CAR-T therapy, patients (especially children) who have not completed a vaccination program need to restart vaccination after an appropriate amount of time. Given the lack of evidence for such special population, the current best choice consists of vaccination 
until the B cell recovery [100]. The B cell aplasia represents circumstantial evidence of the persistent efficiency and existence of CAR-T cells. The persistent B cell aplasia implies that CAR-T cells in vivo exert immune surveillance for target antigen-positive lymphoma cells and are correlated with a durable clinical response [101].

\section{Current challenges and prospects of the CAR-T therapy}

\section{Broadening the therapeutic indications of the CAR-T therapy for lymphoma}

The success of the CAR-T cell therapy in the treatment of B-NHL is remarkable. However, the clinical results of the CAR-T therapy for lymphoma have been derived from several pivotal clinical trials involving DLBCL due to the high morbidity of DLBCL in B-NHL. Other than CD19-, CD20-, or CD22-positive R/R B-NHL, diseases, such as precursor B cell lymphoblastic lymphoma, BL [102], MCL, FL, and CLL/SLL, should also be considered in CAR-T clinical trials. The ZUMA-2, a phase II multicenter global clinical trial, has assessed the efficacy and the safety of the use of axicabtagene ciloleucel for the treatment of patients with $\mathrm{R} / \mathrm{R}$ MCL. A total of 28 patients with $\mathrm{R} / \mathrm{R}$ $\mathrm{CD} 19^{+} \mathrm{MCL}$ are recruited, and each patient has received the anti-CD19 CAR-T cell infusion at a median dose of $2 \times 10^{6}$ per $\mathrm{kg}$. The OR and the CR rates are $86 \%$ and $57 \%$, respectively. With a median follow-up period of 13.2 months, the estimated 1-year duration of response, PFS rate, and OS rate are $86 \%, 71 \%$, and $86 \%$, respectively [103]. Universal CAR-T cells from third-party donors, allogenic CAR-T from haploidentical donors and HLAmatched donors, or universal CAR-NK cells from cord blood [104] represent a potential strategy for patients who are unable to receive the autologous CAR-T treatment due to rapid disease progression, failure of CAR-T generation, or pre-existing immunodeficiency conditions, such as acquired immune deficiency syndrome (AIDS).

The CAR-T cellular therapy is approved for the thirdline salvage therapy. With a reduction in the cost of the CAR-T manufacturing and an improvement in the safety of its clinical use, the CAR-T cell therapy can be upgraded to a second- or even first-line therapy [105]. In this case, patients with lymphoma can be cured using the CAR-T treatment in the early stage and does not have to undergo conventional chemotherapy regimens. The CD30, a much-anticipated new target antigen, may broaden the indications of CAR-T therapy for R/R HL, ALCL, lymphomatoid papulosis, and other $\mathrm{T}$ cell lymphomas. However, further phase 2 clinical trials should be performed to evaluate its efficacy and safety. Furthermore, new target antigens for NK/T cell NHLs, including CD4 (NCT03829540) [106], CD7 (NCT03690011) [107],
CD30 (NCT04083495), and CD37 (NCT04136275) [65], are suggested.

The main obstacles in the identification of novel target antigens for NK/T cell NHLs are fratricide between CAR$T$ cells due to the presence of pan-T cell antigens [108] and $\mathrm{T}$ cell aplasia, which is also known as the on-target offtumor effect. The knockout of pan-T cell antigen genes by using gene editing techniques after the transduction of antipan-T cell antigen $C A R$ gene may be an effective method to avoid the CAR-T fratricide. Moreover, the long-term T cell aplasia may lead to a similar condition to that observed in the AIDS. This condition may cause undesirable effects, including opportunistic infection and secondary tumors. Hence, the use of anti-NK/T cell NHL CAR-T therapy requires additional considerations because it may result in long-term $\mathrm{T}$ cell aplasia.

\section{Enhancing the efficacy and the persistence of CAR-T cells and overcoming the tumor-protecting effect for long-term survival}

To date, about half of the patients with $R / R$ B cell lymphoma who have received the CAR-T cell therapy in clinical trials have achieved CR. However, the other half of these patients have either relapsed or become refractory to the CAR-T cell therapy. An unsatisfactory CR rate related to the short PFS has become one of the major problems associated with the use of the CAR-T cell therapy for lymphoma. Compared with the high CR rate of R/R ALL and other precursor $\mathrm{B}$ cell-derived hematological malignancies, the heterogeneity of lymphoma cells and the TME may contribute to the low CR rate of patients with lymphoma after the CAR-T therapy [109]. The expression of the targeted antigens on lymphoma cells varies from one cell to another. Some lymphoma cells present low-density or no targeted antigens. This low affinity to CAR-T cells results in resistance to the tumor-killing effect of CAR-T cells [54,110-113]. Although high-density targeted antigen lymphoma cells are eliminated by CAR-T cells, lowdensity targeted antigen lymphoma cells tend to proliferate again and result in a relapse from short-term response or progressive diseases. Three strategies have been suggested under clinical trial evaluations to overcome the heterogeneity of antigen expression: (1) optimize the sequence of extracellular domains to increase the affinity of CARs and tumor-specific antigen [114]; (2) combine two or more monospecific CAR-T cells to cover broad-spectrum lymphoma cells $[115,116]$; (3) generate multispecific CAR-T cells that express multiple CARs on a single CAR-T cell (bicistronic CAR) [117] or a single CAR with two or more recognizing domains (tandem CAR) [34,118121].

In addition, the TME in lymphoma is another important factor that leads to resistance to the tumor-killing effect of CAR-T cells. The gene expression in baseline tumor 
samples, such as tumor-associated macrophages (i.e., CXCL2 and CXCL8), myeloid-derived suppressor cells (i.e., CXCL12, CCL3, CCL4, and CCL5), immunosuppressive cytokines (i.e., IL10 and TGF $\beta 1$ ), tumor-associated dendritic cells (i.e., CD33 and CD14), and tumorassociated fibroblasts (i.e., FAP, TNC, CSPG4, PDGFRA, S100A4, ASPN, STC1, and ITGAM) in patients with PR $\mathrm{R} / \mathrm{R}$ B-NHL is higher than that in patients with CR R/R BNHL after the CAR-T treatment. Compared with those of patients with $\mathrm{CR}$, the baseline tumor samples of patients with PR are characterized with low levels of the gene expression of chemokines (i.e., CCR6, CCR10, CXCR3, and CXCR4) and adhesion molecules (i.e., CD226, ITGAE, TNFRSF18). Increased tumor-associated macrophage infiltration and decreased tumor-infiltrating $\mathrm{T}$ cells in lymphoma are correlated with negative remission after the CAR-T therapy [122].

Besides, CD80, CD86, PDL1, PDL2, MHC class II, Galectin 9, and CEACAM1, which are largely expressed by antigen presenting cells or target cells, may cause the CAR-T cell exhaustion, which also results in poor $\mathrm{T}$ cell expansion or short-term $\mathrm{T}$ cell persistence [123]. In a clinical trial for R/R CLL, the preinfusion of CAR-T cells from the upregulated pathway of nonresponder patients is associated with apoptosis and exhaustion. The upregulation of coinhibitory molecules, such as PD-1, TIM-3, and LAG-3, on CAR-T cells indicates that the immune checkpoint pathway plays an important role in regulating the inhibitory effect on CAR-T cells [124]. The addition of an immune checkpoint blockade may reverse the exhaustion of CAR-T cells and maintain the tumor-killing effect and the persistence of CAR-T cells [125-127].

Other strategies for immune checkpoints, such as armored CAR-T cells secreting PD-L1 antibody [128], bispecific CAR-T targeting PD-L1, and tumor-specific antigen [129], represent potential solutions to counteract the CAR-T cell exhaustion. Moreover, the modification of condition regimens, such as intensive chemotherapy with autologous HSCT [130,131] and radiation [132,133], prior to the infusion of CAR-T cells may destroy the TME and improve the clinical outcomes of the CAR-T therapy.

\section{Reducing life-threatening adverse events in the CAR-T cell therapy}

Another limitation of the CAR-T therapy is its adverse effects. As mentioned previously, the CRS is a major side effect of the CAR-T therapy. In addition to the application of cytokine monoclonal antibodies, the use of other small molecule agents, such as dasatinib [134,135], and the modification of the CAR-T cell structure, such as the development of a safety switch, should be explored in future studies $[32,33]$. Improving the understanding of the CAR-T among doctors and nurses is the key to decrease the mortality rate of the CAR-T therapy. With a safe and effective CAR-T cell therapy, immunotherapy will play an indispensable role in the treatment of lymphoma in the future.

\section{Acknowledgements}

This work was supported by grants from the National Natural Science Foundation of China (Nos. 81230014, 81470341, 81520108002, and 81500157), the Key Project of Science and Technology Department of Zhejiang Province (No. 2018C03016-2), and the Key Research and Development Program of Zhejiang Province (No. 2019C03016).

\section{Compliance with ethics guidelines}

Houli Zhao, Yiyun Wang, Elaine Tan Su Yin, Kui Zhao, Yongxian $\mathrm{Hu}$, and $\mathrm{He}$ Huang declare that they have no conflict of interest. This manuscript is a review article and does not involve a research protocol requiring approval by the relevant institutional review board or ethics committee.

Open Access This article is licensed under a Creative Commons Attribution 4.0 International License, which permits use, sharing, adaptation, distribution and reproduction in any medium or format, as long as you give appropriate credit to the original author(s) and the source, provide a link to the Creative Commons license, and indicate if changes were made.

The images or other third party material in this article are included in the article's Creative Commons license, unless indicated otherwise in a credit line to the material. If material is not included in the article's Creative Commons license and your intended use is not permitted by statutory regulation or exceeds the permitted use, you will need to obtain permission directly from the copyright holder.

To view a copy of this license, visit https://creativecommons.org/ licenses/by/4.0/.

\section{References}

1. WHO. WHO classification of tumours of haematopoietic and lymphoid tissue. 4th ed. Geneva: World Health Organization, 2008

2. Siegel RL, Miller KD, Jemal A. Cancer statistics, 2019. CA Cancer J Clin 2019; 69(1): 7-34

3. Zhang Y, Tuo J, Zheng R, Zhang S, Zhang M, Li G, Yang N, Lu W, Chen W. An analysis of incidence and mortality of malignant lymphoma in China, 2009. China Cancer 2013; 22: 338-343

4. Canellos GP, Anderson JR, Propert KJ, Nissen N, Cooper MR, Henderson ES, Green MR, Gottlieb A, Peterson BA. Chemotherapy of advanced Hodgkin's disease with MOPP, ABVD, or MOPP alternating with ABVD. N Engl J Med 1992; 327(21): 1478-1484

5. Coiffier B, Thieblemont C, Van Den Neste E, Lepeu G, Plantier I, Castaigne S, Lefort S, Marit G, Macro M, Sebban C, Belhadj K, Bordessoule D, Fermé C, Tilly H. Long-term outcome of patients in the LNH-98.5 trial, the first randomized study comparing 
rituximab-CHOP to standard CHOP chemotherapy in DLBCL patients: a study by the Groupe d'Etudes des Lymphomes de l'Adulte. Blood 2010; 116(12): 2040-2045

6. Pfreundschuh M, Kuhnt E, Trümper L, Osterborg A, Trneny M, Shepherd L, Gill DS, Walewski J, Pettengell R, Jaeger U, Zinzani PL, Shpilberg O, Kvaloy S, de Nully Brown P, Stahel R, Milpied $\mathrm{N}$, López-Guillermo A, Poeschel V, Grass S, Loeffler M, Murawski N, MabThera International Trial (MInT) Group. CHOP-like chemotherapy with or without rituximab in young patients with good-prognosis diffuse large-B-cell lymphoma: 6year results of an open-label randomised study of the MabThera International Trial (MInT) Group. Lancet Oncol 2011; 12(11): 1013-1022

7. Armitage JO, Gascoyne RD, Lunning MA, Cavalli F. NonHodgkin lymphoma. Lancet 2017; 390(10091): 298-310

8. Hu Y, Wu Z, Luo Y, Shi J, Yu J, Pu C, Liang Z, Wei G, Cui Q, Sun J, Jiang J, Xie J, Tan Y, Ni W, Tu J, Wang J, Jin A, Zhang H, Cai Z, Xiao L, Huang H. Potent anti-leukemia activities of chimeric antigen receptor-modified T cells against CD19 in Chinese patients with relapsed/refractory acute lymphocytic leukemia. Clin Cancer Res 2017; 23(13): 3297-3306

9. Mueller KT, Waldron E, Grupp SA, Levine JE, Laetsch TW, Pulsipher MA, Boyer MW, August KJ, Hamilton J, Awasthi R, Stein AM, Sickert D, Chakraborty A, Levine BL, June CH, Tomassian L, Shah SS, Leung M, Taran T, Wood PA, Maude SL. Clinical pharmacology of tisagenlecleucel in B-cell acute lymphoblastic leukemia. Clin Cancer Res 2018; 24(24): 6175-6184

10. Kochenderfer JN, Dudley ME, Kassim SH, Somerville RP, Carpenter RO, Stetler-Stevenson M, Yang JC, Phan GQ, Hughes MS, Sherry RM, Raffeld M, Feldman S, Lu L, Li YF, Ngo LT, Goy A, Feldman T, Spaner DE, Wang ML, Chen CC, Kranick SM, Nath A, Nathan DA, Morton KE, Toomey MA, Rosenberg SA. Chemotherapy-refractory diffuse large B-cell lymphoma and indolent B-cell malignancies can be effectively treated with autologous $\mathrm{T}$ cells expressing an anti-CD19 chimeric antigen receptor. J Clin Oncol 2015; 33(6): 540-549

11. Schuster SJ, Bishop MR, Tam CS, Waller EK, Borchmann P, McGuirk JP, Jäger U, Jaglowski S, Andreadis C, Westin JR, Fleury I, Bachanova V, Foley SR, Ho PJ, Mielke S, Magenau JM, Holte H, Pantano S, Pacaud LB, Awasthi R, Chu J, Anak Ö, Salles G, Maziarz RT, JULIET Investigators. Tisagenlecleucel in adult relapsed or refractory diffuse large B-cell lymphoma. N Engl J Med 2019; 380(1): 45-56

12. Locke FL, Ghobadi A, Jacobson CA, Miklos DB, Lekakis LJ, Oluwole OO, Lin Y, Braunschweig I, Hill BT, Timmerman JM, Deol A, Reagan PM, Stiff P, Flinn IW, Farooq U, Goy A, McSweeney PA, Munoz J, Siddiqi T, Chavez JC, Herrera AF, Bartlett NL, Wiezorek JS, Navale L, Xue A, Jiang Y, Bot A, Rossi JM, Kim JJ, Go WY, Neelapu SS. Long-term safety and activity of axicabtagene ciloleucel in refractory large B-cell lymphoma (ZUMA-1): a single-arm, multicentre, phase 1-2 trial. Lancet Oncol 2019; 20(1): 31-42

13. Campana D, Schwarz H, Imai C. 4-1BB chimeric antigen receptors. Cancer J 2014; 20(2): 134-140

14. Gross G, Waks T, Eshhar Z. Expression of immunoglobulin-T-cell receptor chimeric molecules as functional receptors with antibodytype specificity. Proc Natl Acad Sci USA 1989; 86(24): 10024
10028

15. Kuwana Y, Asakura Y, Utsunomiya N, Nakanishi M, Arata Y, Itoh S, Nagase F, Kurosawa Y. Expression of chimeric receptor composed of immunoglobulin-derived $\mathrm{V}$ regions and $\mathrm{T}$-cell receptor-derived $\mathrm{C}$ regions. Biochem Biophys Res Commun 1987; 149(3): 960-968

16. Eshhar Z, Waks T, Gross G, Schindler DG. Specific activation and targeting of cytotoxic lymphocytes through chimeric single chains consisting of antibody-binding domains and the gamma or zeta subunits of the immunoglobulin and T-cell receptors. Proc Natl Acad Sci USA 1993; 90(2): 720-724

17. Brentjens RJ, Latouche JB, Santos E, Marti F, Gong MC, Lyddane C, King PD, Larson S, Weiss M, Rivière I, Sadelain M. Eradication of systemic B-cell tumors by genetically targeted human $\mathrm{T}$ lymphocytes co-stimulated by CD80 and interleukin-15. Nat Med 2003; 9(3): 279-286

18. Maher J, Brentjens RJ, Gunset G, Rivière I, Sadelain M. Human Tlymphocyte cytotoxicity and proliferation directed by a single chimeric TCR $\zeta / C D 28$ receptor. Nat Biotechnol 2002; 20(1): 7075

19. Imai C, Mihara K, Andreansky M, Nicholson IC, Pui CH, Geiger TL, Campana D. Chimeric receptors with 4-1BB signaling capacity provoke potent cytotoxicity against acute lymphoblastic leukemia. Leukemia 2004; 18(4): 676-684

20. Kochenderfer JN, Wilson WH, Janik JE, Dudley ME, StetlerStevenson M, Feldman SA, Maric I, Raffeld M, Nathan DA, Lanier BJ, Morgan RA, Rosenberg SA. Eradication of B-lineage cells and regression of lymphoma in a patient treated with autologous $\mathrm{T}$ cells genetically engineered to recognize CD19. Blood 2010; 116(20): 4099-4102

21. Pulè MA, Straathof KC, Dotti G, Heslop HE, Rooney CM, Brenner MK. A chimeric $\mathrm{T}$ cell antigen receptor that augments cytokine release and supports clonal expansion of primary human $\mathrm{T}$ cells. Mol Ther 2005; 12(5): 933-941

22. Wang J, Jensen M, Lin Y, Sui X, Chen E, Lindgren CG, Till B, Raubitschek A, Forman SJ, Qian X, James S, Greenberg P, Riddell $\mathrm{S}$, Press OW. Optimizing adoptive polyclonal T cell immunotherapy of lymphomas, using a chimeric $\mathrm{T}$ cell receptor possessing CD28 and CD137 costimulatory domains. Hum Gene Ther 2007; 18(8): 712-725

23. Wilkie S, Picco G, Foster J, Davies DM, Julien S, Cooper L, Arif S, Mather SJ, Taylor-Papadimitriou J, Burchell JM, Maher J. Retargeting of human $\mathrm{T}$ cells to tumor-associated MUC1: the evolution of a chimeric antigen receptor. J Immunol 2008; 180(7): 4901-4909

24. Carpenito C, Milone MC, Hassan R, Simonet JC, Lakhal M, Suhoski MM, Varela-Rohena A, Haines KM, Heitjan DF, Albelda SM, Carroll RG, Riley JL, Pastan I, June CH. Control of large, established tumor xenografts with genetically retargeted human $\mathrm{T}$ cells containing CD28 and CD137 domains. Proc Natl Acad Sci USA 2009; 106(9): 3360-3365

25. Tammana S, Huang X, Wong M, Milone MC, Ma L, Levine BL, June CH, Wagner JE, Blazar BR, Zhou X. 4-1BB and CD28 signaling plays a synergistic role in redirecting umbilical cord blood T cells against B-cell malignancies. Hum Gene Ther 2010; 21(1): 75-86

26. Zhong XS, Matsushita M, Plotkin J, Riviere I, Sadelain M. 
Chimeric antigen receptors combining 4-1BB and CD28 signaling domains augment PI3kinase/AKT/Bcl-XL activation and CD8 ${ }^{+} \mathrm{T}$ cell-mediated tumor eradication. Mol Ther 2010; 18(2): 413-420

27. Hombach AA, Chmielewski M, Rappl G, Abken H. Adoptive immunotherapy with redirected $\mathrm{T}$ cells produces CCR ${ }^{-}$cells that are trapped in the periphery and benefit from combined CD28OX40 costimulation. Hum Gene Ther 2013; 24(3): 259-269

28. Duong CP, Westwood JA, Yong CS, Murphy A, Devaud C, John LB, Darcy PK, Kershaw MH. Engineering T cell function using chimeric antigen receptors identified using a DNA library approach. PLoS One 2013; 8(5): e63037

29. Till BG, Jensen MC, Wang J, Qian X, Gopal AK, Maloney DG, Lindgren CG, Lin Y, Pagel JM, Budde LE, Raubitschek A, Forman SJ, Greenberg PD, Riddell SR, Press OW. CD20-specific adoptive immunotherapy for lymphoma using a chimeric antigen receptor with both $\mathrm{CD} 28$ and 4-1BB domains: pilot clinical trial results. Blood 2012; 119(17): 3940-3950

30. Chen Y, Sun C, Landoni E, Metelitsa L, Dotti G, Savoldo B. Eradication of neuroblastoma by $\mathrm{T}$ cells redirected with an optimized GD2-specific chimeric antigen receptor and interleukin-15. Clin Cancer Res 2019; 25(9): 2915-2924

31. Zhao Z, Condomines M, van der Stegen SJC, Perna F, Kloss CC, Gunset G, Plotkin J, Sadelain M. Structural design of engineered costimulation determines tumor rejection kinetics and persistence of CAR T cells. Cancer Cell 2015; 28(4): 415-428

32. Diaconu I, Ballard B, Zhang M, Chen Y, West J, Dotti G, Savoldo B. Inducible caspase-9 selectively modulates the toxicities of CD19-specific chimeric antigen receptor-modified T cells. Mol Ther 2017; 25(3): 580-592

33. Sakemura R, Terakura S, Watanabe K, Julamanee J, Takagi E, Miyao K, Koyama D, Goto T, Hanajiri R, Nishida T, Murata M, Kiyoi H. A Tet-On inducible system for controlling CD19chimeric antigen receptor expression upon drug administration. Cancer Immunol Res 2016; 4(8): 658-668

34. Zhao J, Lin Q, Song Y, Liu D. Universal CARs, universal T cells, and universal CAR T cells. J Hematol Oncol 2018; 11(1): 132

35. Cho JH, Collins JJ, Wong WW. Universal chimeric antigen receptors for multiplexed and logical control of $\mathrm{T}$ cell responses. Cell 2018; 173(6): 1426-1438.e11

36. Urbanska K, Lanitis E, Poussin M, Lynn RC, Gavin BP, Kelderman S, Yu J, Scholler N, Powell DJ Jr. A universal strategy for adoptive immunotherapy of cancer through use of a novel Tcell antigen receptor. Cancer Res 2012; 72(7): 1844-1852

37. Liu D, Zhao J, Song Y. Engineering switchable and programmable universal CARs for CAR T therapy. J Hematol Oncol 2019; 12(1): 69

38. Kim MS, Ma JS, Yun H, Cao Y, Kim JY, Chi V, Wang D, Woods A, Sherwood L, Caballero D, Gonzalez J, Schultz PG, Young TS, Kim CH. Redirection of genetically engineered CAR-T cells using bifunctional small molecules. J Am Chem Soc 2015; 137(8): 2832-2835

39. Hung CF, Xu X, Li L, Ma Y, Jin Q, Viley A, Allen C, Natarajan P, Shivakumar R, Peshwa MV, Emens LA. Development of antihuman mesothelin-targeted chimeric antigen receptor messenger RNA-transfected peripheral blood lymphocytes for ovarian cancer therapy. Hum Gene Ther 2018; 29(5): 614-625

40. Crossland DL, Denning WL, Ang S, Olivares S, Mi T, Switzer K,
Singh H, Huls H, Gold KS, Glisson BS, Cooper LJ, Heymach JV. Antitumor activity of CD56-chimeric antigen receptor T cells in neuroblastoma and SCLC models. Oncogene 2018; 37(27): 36863697

41. Kebriaei P, Singh H, Huls MH, Figliola MJ, Bassett R, Olivares S, Jena B, Dawson MJ, Kumaresan PR, Su S, Maiti S, Dai J, Moriarity B, Forget MA, Senyukov V, Orozco A, Liu T, McCarty J, Jackson RN, Moyes JS, Rondon G, Qazilbash M, Ciurea S, Alousi A, Nieto Y, Rezvani K, Marin D, Popat U, Hosing C, Shpall EJ, Kantarjian H, Keating M, Wierda W, Do KA, Largaespada DA, Lee DA, Hackett PB, Champlin RE, Cooper LJ. Phase I trials using Sleeping Beauty to generate CD19-specific CAR T cells. J Clin Invest 2016; 126(9): 3363-3376

42. Turtle CJ, Berger C, Sommermeyer D, Hanafi LA, Pender B, Robinson EM, Melville K, Budiarto TM, Steevens NN, Chaney C, Cherian S, Wood BL, Soma L, Chen X, Heimfeld S, Jensen MC, Riddell SR, Maloney DG. Anti-CD19 chimeric antigen receptormodified $\mathrm{T}$ cell therapy for $\mathrm{B}$ cell non-Hodgkin lymphoma and chronic lymphocytic leukemia: fludarabine and cyclophosphamide lymphodepletion improves in vivo expansion and persistence of CAR-T cells and clinical outcomes. Blood 2015; 126(23): 184

43. Heczey A, Louis CU, Savoldo B, Dakhova O, Durett A, Grilley B, Liu H, Wu MF, Mei Z, Gee A, Mehta B, Zhang H, Mahmood N, Tashiro H, Heslop HE, Dotti G, Rooney CM, Brenner MK. CAR T cells administered in combination with lymphodepletion and PD-1 inhibition to patients with neuroblastoma. Mol Ther 2017; 25(9): 2214-2224

44. Ninomiya S, Narala N, Huye L, Yagyu S, Savoldo B, Dotti G, Heslop HE, Brenner MK, Rooney CM, Ramos CA. Tumor indoleamine 2,3-dioxygenase (IDO) inhibits CD19-CAR T cells and is downregulated by lymphodepleting drugs. Blood 2015; 125 (25): 3905-3916

45. Hirayama AV, Gauthier J, Hay KA, Voutsinas JM, Wu Q, Gooley T, Li D, Cherian S, Chen X, Pender BS, Hawkins RM, Vakil A, Steinmetz RN, Acharya UH, Cassaday RD, Chapuis AG, Dhawale TM, Hendrie PC, Kiem HP, Lynch RC, Ramos J, Shadman M, Till BG, Riddell SR, Maloney DG, Turtle CJ. The response to lymphodepletion impacts PFS in patients with aggressive nonHodgkin lymphoma treated with CD19 CAR T cells. Blood 2019; 133(17): 1876-1887

46. Boomer JS, Green JM. An enigmatic tail of CD28 signaling. Cold Spring Harb Perspect Biol 2010; 2(8): a002436

47. Chester C, Sanmamed MF, Wang J, Melero I. Immunotherapy targeting 4-1BB: mechanistic rationale, clinical results, and future strategies. Blood 2018; 131(1): 49-57

48. Kawalekar OU, O'Connor RS, Fraietta JA, Guo L, McGettigan SE, Posey AD Jr, Patel PR, Guedan S, Scholler J, Keith B, Snyder NW, Blair IA, Milone MC, June CH. Distinct signaling of coreceptors regulates specific metabolism pathways and impacts memory development in CAR T cells. Immunity 2016; 44(2): 380-390

49. Wang J, Press OW, Lindgren CG, Greenberg P, Riddell S, Qian X, Laugen C, Raubitschek A, Forman SJ, Jensen MC. Cellular immunotherapy for follicular lymphoma using genetically modified CD20-specific $\mathrm{CD}^{+}$cytotoxic $\mathrm{T}$ lymphocytes. Mol Ther 2004; 9(4): 577-586

50. James SE, Orgun NN, Tedder TF, Shlomchik MJ, Jensen MC, Lin Y, Greenberg PD, Press OW. Antibody-mediated B-cell depletion 
before adoptive immunotherapy with $\mathrm{T}$ cells expressing CD20specific chimeric T-cell receptors facilitates eradication of leukemia in immunocompetent mice. Blood 2009; 114(27): 5454-5463

51. Zhang WY, Liu Y, Wang Y, Wang CM, Yang QM, Zhu HL, Han WD. Long-term safety and efficacy of CART-20 cells in patients with refractory or relapsed B-cell non-Hodgkin lymphoma: 5-years follow-up results of the phase I and IIa trials. Signal Transduct Target Ther 2017; 2(1): 17054

52. Haso W, Lee DW, Shah NN, Stetler-Stevenson M, Yuan CM, Pastan IH, Dimitrov DS, Morgan RA, FitzGerald DJ, Barrett DM, Wayne AS, Mackall CL, Orentas RJ. Anti-CD22-chimeric antigen receptors targeting B-cell precursor acute lymphoblastic leukemia. Blood 2013; 121(7): 1165-1174

53. Shalabi H, Wolters PL, Martin S, Toledo-Tamula MA, Roderick MC, Struemph K, Kane E, Yates B, Delbrook C, Mackall CL, Lee DW, Fry TJ, Shah NN. Systematic evaluation of neurotoxicity in children and young adults undergoing CD22 chimeric antigen receptor T-cell therapy. J Immunother 2018; 41(7): 350-358

54. Fry TJ, Shah NN, Orentas RJ, Stetler-Stevenson M, Yuan CM, Ramakrishna S, Wolters P, Martin S, Delbrook C, Yates B, Shalabi H, Fountaine TJ, Shern JF, Majzner RG, Stroncek DF, Sabatino M, Feng Y, Dimitrov DS, Zhang L, Nguyen S, Qin H, Dropulic B, Lee DW, Mackall CL. CD22-targeted CAR T cells induce remission in B-ALL that is naive or resistant to CD19-targeted CAR immunotherapy. Nat Med 2018; 24(1): 20-28

55. Dürkop H, Latza U, Hummel M, Eitelbach F, Seed B, Stein H. Molecular cloning and expression of a new member of the nerve growth factor receptor family that is characteristic for Hodgkin's disease. Cell 1992; 68(3): 421-427

56. Pierce JM, Mehta A. Diagnostic, prognostic and therapeutic role of CD30 in lymphoma. Expert Rev Hematol 2017; 10(1): 29-37

57. Horie R, Watanabe T. CD30: expression and function in health and disease. Semin Immunol 1998; 10(6): 457-470

58. Falini B, Pileri S, Pizzolo G, Dürkop H, Flenghi L, Stirpe F, Martelli MF, Stein H. CD30 (Ki-1) molecule: a new cytokine receptor of the tumor necrosis factor receptor superfamily as a tool for diagnosis and immunotherapy. Blood 1995; 85(1): 1-14

59. Hombach A, Heuser C, Sircar R, Tillmann T, Diehl V, Pohl C, Abken H. An anti-CD30 chimeric receptor that mediates CD3- $\zeta$ independent T-cell activation against Hodgkin's lymphoma cells in the presence of soluble CD30. Cancer Res 1998; 58(6): 1116-1119

60. Savoldo B, Rooney CM, Di Stasi A, Abken H, Hombach A, Foster AE, Zhang L, Heslop HE, Brenner MK, Dotti G. Epstein Barr virus specific cytotoxic $\mathrm{T}$ lymphocytes expressing the anti-CD30 $\zeta$ artificial chimeric T-cell receptor for immunotherapy of Hodgkin disease. Blood 2007; 110(7): 2620-2630

61. Ramos CA, Ballard B, Zhang H, Dakhova O, Gee AP, Mei Z, Bilgi M, Wu MF, Liu H, Grilley B, Bollard CM, Chang BH, Rooney CM, Brenner MK, Heslop HE, Dotti G, Savoldo B. Clinical and immunological responses after CD30-specific chimeric antigen receptor-redirected lymphocytes. J Clin Invest 2017; 127(9): $3462-3471$

62. Wang CM, Wu ZQ, Wang Y, Guo YL, Dai HR, Wang XH, Li X, Zhang YJ, Zhang WY, Chen MX, Zhang Y, Feng KC, Liu Y, Li SX, Yang QM, Han WD. Autologous T cells expressing CD30 chimeric antigen receptors for relapsed or refractory Hodgkin lymphoma: an open-label phase I trial. Clin Cancer Res 2017; 23 (5): 1156-1166

63. Barrena S, Almeida J, Yunta M, López A, Fernández-Mosteirín N, Giralt M, Romero M, Perdiguer L, Delgado M, Orfao A, Lazo PA. Aberrant expression of tetraspanin molecules in B-cell chronic lymphoproliferative disorders and its correlation with normal Bcell maturation. Leukemia 2005; 19(8): 1376-1383

64. Pereira DS, Guevara CI, Jin L, Mbong N, Verlinsky A, Hsu SJ, Aviña H, Karki S, Abad JD, Yang P, Moon SJ, Malik F, Choi MY, An Z, Morrison K, Challita-Eid PM, Doñate F, Joseph IB, Kipps TJ, Dick JE, Stover DR. AGS67E, an anti-CD37 monomethyl auristatin $\mathrm{E}$ antibody-drug conjugate as a potential therapeutic for B/T-cell malignancies and AML: a new role for CD37 in AML. Mol Cancer Ther 2015; 14(7): 1650-1660

65. Scarfò I, Ormhøj M, Frigault MJ, Castano AP, Lorrey S, Bouffard AA, van Scoyk A, Rodig SJ, Shay AJ, Aster JC, Preffer FI, Weinstock DM, Maus MV. Anti-CD37 chimeric antigen receptor T cells are active against B- and T-cell lymphomas. Blood 2018; 132 (14): 1495-1506

66. Köksal H, Dillard P, Josefsson SE, Maggadottir SM, Pollmann S, Fåne A, Blaker YN, Beiske K, Huse K, Kolstad A, Holte H, Kvalheim G, Smeland EB, Myklebust JH, Inderberg EM, Wälchli S. Preclinical development of CD37CAR T-cell therapy for treatment of B-cell lymphoma. Blood Adv 2019; 3(8): 1230-1243

67. Ruella M, Xu J, Barrett DM, Fraietta JA, Reich TJ, Ambrose DE, Klichinsky M, Shestova O, Patel PR, Kulikovskaya I, Nazimuddin F, Bhoj VG, Orlando EJ, Fry TJ, Bitter H, Maude SL, Levine BL, Nobles CL, Bushman FD, Young RM, Scholler J, Gill SI, June CH, Grupp SA, Lacey SF, Melenhorst JJ. Induction of resistance to chimeric antigen receptor $\mathrm{T}$ cell therapy by transduction of a single leukemic B cell. Nat Med 2018; 24(10): 1499-1503

68. Calvo KR, McCoy CS, Stetler-Stevenson M. Flow cytometry immunophenotyping of hematolymphoid neoplasia. Methods Mol Biol 2011; 699: 295-316

69. Craig FE, Foon KA. Flow cytometric immunophenotyping for hematologic neoplasms. Blood 2008; 111(8): 3941-3967

70. Vera J, Savoldo B, Vigouroux S, Biagi E, Pule M, Rossig C, Wu J, Heslop HE, Rooney CM, Brenner MK, Dotti G. T lymphocytes redirected against the $\kappa$ light chain of human immunoglobulin efficiently kill mature B lymphocyte-derived malignant cells. Blood 2006; 108(12): 3890-3897

71. Ramos CA, Savoldo B, Torrano V, Ballard B, Zhang H, Dakhova O, Liu E, Carrum G, Kamble RT, Gee AP, Mei Z, Wu MF, Liu H, Grilley B, Rooney CM, Brenner MK, Heslop HE, Dotti G. Clinical responses with $\mathrm{T}$ lymphocytes targeting malignancy-associated $\kappa$ light chains. J Clin Invest 2016; 126(7): 2588-2596

72. Wang J, Hu Y, Yang S, Wei G, Zhao X, Wu W, Zhang Y, Zhang Y, Chen D, Wu Z, Xiao L, Chang AH, Huang H, Zhao K. Role of fluorodeoxyglucose positron emission tomography/computed tomography in predicting the adverse effects of chimeric antigen receptor $\mathrm{T}$ cell therapy in patients with non-Hodgkin lymphoma. Biol Blood Marrow Transplant 2019; 25(6): 1092-1098

73. Giavridis T, van der Stegen SJC, Eyquem J, Hamieh M, Piersigilli A, Sadelain M. CAR T cell-induced cytokine release syndrome is mediated by macrophages and abated by IL-1 blockade. Nat Med 2018; 24(6): 731-738

74. Norelli M, Camisa B, Barbiera G, Falcone L, Purevdorj A, Genua 
M, Sanvito F, Ponzoni M, Doglioni C, Cristofori P, Traversari C, Bordignon C, Ciceri F, Ostuni R, Bonini C, Casucci M, Bondanza A. Monocyte-derived IL-1 and IL-6 are differentially required for cytokine-release syndrome and neurotoxicity due to CAR T cells. Nat Med 2018; 24(6): 739-748

75. Teachey DT, Lacey SF, Shaw PA, Melenhorst JJ, Maude SL, Frey N, Pequignot E, Gonzalez VE, Chen F, Finklestein J, Barrett DM, Weiss SL, Fitzgerald JC, Berg RA, Aplenc R, Callahan C, Rheingold SR, Zheng Z, Rose-John S, White JC, Nazimuddin F, Wertheim G, Levine BL, June CH, Porter DL, Grupp SA. Identification of predictive biomarkers for cytokine release syndrome after chimeric antigen receptor T-cell therapy for acute lymphoblastic leukemia. Cancer Discov 2016; 6(6): 664-679

76. Wang J, Hu Y, Huang H. Current development of chimeric antigen receptor T-cell therapy. Stem Cell Investig 2018; 5: 44

77. Neelapu SS, Tummala S, Kebriaei P, Wierda W, Gutierrez C, Locke FL, Komanduri KV, Lin Y, Jain N, Daver N, Westin J, Gulbis AM, Loghin ME, de Groot JF, Adkins S, Davis SE, Rezvani K, Hwu P, Shpall EJ. Chimeric antigen receptor T-cell therapy-assessment and management of toxicities. Nat Rev Clin Oncol 2018; 15(1): 47-62

78. Lee DW, Gardner R, Porter DL, Louis CU, Ahmed N, Jensen M, Grupp SA, Mackall CL. Current concepts in the diagnosis and management of cytokine release syndrome. Blood 2014; 124(2): 188-195

79. Park JH, Rivière I, Gonen M, Wang X, Sénéchal B, Curran KJ, Sauter C, Wang Y, Santomasso B, Mead E, Roshal M, Maslak P, Davila M, Brentjens RJ, Sadelain M. Long-term follow-up of CD19 CAR therapy in acute lymphoblastic leukemia. N Engl J Med 2018; 378(5): 449-459

80. Porter D, Frey N, Wood PA, Weng Y, Grupp SA. Grading of cytokine release syndrome associated with the CAR T cell therapy tisagenlecleucel. J Hematol Oncol 2018; 11(1): 35

81. Lee DW, Santomasso BD, Locke FL, Ghobadi A, Turtle CJ, Brudno JN, Maus MV, Park JH, Mead E, Pavletic S, Go WY, Eldjerou L, Gardner RA, Frey N, Curran KJ, Peggs K, Pasquini M, DiPersio JF, van den Brink MRM, Komanduri KV, Grupp SA, Neelapu SS. ASTCT consensus grading for cytokine release syndrome and neurologic toxicity associated with immune effector cells. Biol Blood Marrow Transplant 2019; 25(4): 625-638

82. Chen F, Teachey DT, Pequignot E, Frey N, Porter D, Maude SL, Grupp SA, June CH, Melenhorst JJ, Lacey SF. Measuring IL-6 and sIL-6R in serum from patients treated with tocilizumab and/or siltuximab following CAR T cell therapy. J Immunol Methods 2016; 434: 1-8

83. Sterner RM, Sakemura R, Cox MJ, Yang N, Khadka RH, Forsman CL, Hansen MJ, Jin F, Ayasoufi K, Hefazi M, Schick KJ, Walters DK, Ahmed O, Chappell D, Sahmoud T, Durrant C, Nevala WK, Patnaik MM, Pease LR, Hedin KE, Kay NE, Johnson AJ, Kenderian SS. GM-CSF inhibition reduces cytokine release syndrome and neuroinflammation but enhances CAR-T cell function in xenografts. Blood 2019; 133(7): 697-709

84. Xiao X, He X, Li Q, Zhang H, Meng J, Jiang Y, Deng Q, Zhao M. Plasma exchange can be an alternative therapeutic modality for severe cytokine release syndrome after chimeric antigen receptor- $\mathrm{T}$ cell infusion: a case report. Clin Cancer Res 2019; 25(1): 29-34

85. Fried S, Avigdor A, Bielorai B, Meir A, Besser MJ, Schachter J, Shimoni A, Nagler A, Toren A, Jacoby E. Early and late hematologic toxicity following CD19 CAR-T cells. Bone Marrow Transplant 2019; 54(10): 1643-1650

86. Jain T, Bar M, Kansagra AJ, Chong EA, Hashmi SK, Neelapu SS, Byrne M, Jacoby E, Lazaryan A, Jacobson CA, Ansell SM, Awan FT, Burns L, Bachanova V, Bollard CM, Carpenter PA, DiPersio JF, Hamadani M, Heslop HE, Hill JA, Komanduri KV, Kovitz CA, Lazarus HM, Serrette JM, Mohty M, Miklos D, Nagler A, Pavletic SZ, Savani BN, Schuster SJ, Kharfan-Dabaja MA, Perales MA, Lin Y. Use of chimeric antigen receptor T cell therapy in clinical practice for relapsed/refractory aggressive B cell non-Hodgkin lymphoma: an expert panel opinion from the American Society for Transplantation and Cellular Therapy. Biol Blood Marrow Transplant 2019; 25(12): 2305-2321

87. Topp MS, Gökbuget N, Stein AS, Zugmaier G, O’Brien S, Bargou RC, Dombret H, Fielding AK, Heffner L, Larson RA, Neumann S, Foà R, Litzow M, Ribera JM, Rambaldi A, Schiller G, Brüggemann M, Horst HA, Holland C, Jia C, Maniar T, Huber B, Nagorsen D, Forman SJ, Kantarjian HM. Safety and activity of blinatumomab for adult patients with relapsed or refractory Bprecursor acute lymphoblastic leukaemia: a multicentre, singlearm, phase 2 study. Lancet Oncol 2015; 16(1): 57-66

88. Hu Y, Sun J, Wu Z, Yu J, Cui Q, Pu C, Liang B, Luo Y, Shi J, Jin A, Xiao L, Huang H. Predominant cerebral cytokine release syndrome in CD19-directed chimeric antigen receptor-modified $\mathrm{T}$ cell therapy. J Hematol Oncol 2016; 9(1): 70

89. Liu D, Zhao J. Cytokine release syndrome: grading, modeling, and new therapy. J Hematol Oncol 2018; 11(1): 121

90. No authors listed. JCAR015 in ALL: a root-cause investigation. Cancer Discov 2018; 8(1): 4-5

91. Abramson JS, McGree B, Noyes S, Plummer S, Wong C, Chen YB, Palmer E, Albertson T, Ferry JA, Arrillaga-Romany IC. AntiCD19 CAR T cells in CNS diffuse large-B-cell lymphoma. N Engl J Med 2017; 377(8): 783-784

92. Lee DW, Kochenderfer JN, Stetler-Stevenson M, Cui YK, Delbrook C, Feldman SA, Fry TJ, Orentas R, Sabatino M, Shah NN, Steinberg SM, Stroncek D, Tschernia N, Yuan C, Zhang H, Zhang L, Rosenberg SA, Wayne AS, Mackall CL. T cells expressing CD19 chimeric antigen receptors for acute lymphoblastic leukaemia in children and young adults: a phase 1 doseescalation trial. Lancet 2015; 385(9967): 517-528

93. Santomasso BD, Park JH, Salloum D, Riviere I, Flynn J, Mead E, Halton E, Wang X, Senechal B, Purdon T, Cross JR, Liu H, Vachha B, Chen X, DeAngelis LM, Li D, Bernal Y, Gonen M, Wendel HG, Sadelain M, Brentjens RJ. Clinical and biological correlates of neurotoxicity associated with CAR T-cell therapy in patients with B-cell acute lymphoblastic leukemia. Cancer Discov 2018; 8(8): 958-971

94. Gust J, Hay KA, Hanafi LA, Li D, Myerson D, Gonzalez-Cuyar LF, Yeung C, Liles WC, Wurfel M, Lopez JA, Chen J, Chung D, Harju-Baker S, Özpolat T, Fink KR, Riddell SR, Maloney DG, Turtle CJ. Endothelial activation and blood-brain barrier disruption in neurotoxicity after adoptive immunotherapy with CD19 CAR-T cells. Cancer Discov 2017; 7(12): 1404-1419

95. Locke FL, Neelapu SS, Bartlett NL, Lekakis LJ, Jacobson CA, Braunschweig I, Oluwole OO, Siddiqi T, Lin Y, Timmerman JM, Reagan PM, Bot A, Rossi JM, Sherman M, Navale L, Jiang Y, Aycock JS, Elias M, Wiezorek JS, Go WY,Miklos DB. Preliminary results of prophylactic tocilizumab after axicabtageneciloleucel 
(axi-cel; KTE-C19) treatment for patients with refractory, aggressive non-Hodgkin lymphoma (NHL). Blood $2017 ; 130$ (Supplement_1): 1547

96. Jin A, Feng J, Wang Z, Jiang L, Hu Y, Zhao K, Huang H. Severe dyspnea caused by rapid enlargement of cervical lymph node in a relapsed/refractory B-cell lymphoma patient following chimeric antigen receptor T-cell therapy. Bone Marrow Transplant 2019; 54 (7): 969-972

97. Hu Y, Wang J, Pu C, Zhao K, Cui Q, Wei G, Wu W, Xiao L, Xiao Y, Wang J, Wu Z, Huang H. Delayed terminal ileal perforation in a relapsed/refractory B-cell lymphoma patient with rapid remission following chimeric antigen receptor T-cell therapy. Cancer Res Treat 2018; 50(4): 1462-1466

98. Hopfinger G, Jäger U, Worel N. CAR-T cell therapy in diffuse large B cell lymphoma: hype and hope. HemaSphere 2019; 3(2): e185

99. Bhoj VG, Arhontoulis D, Wertheim G, Capobianchi J, Callahan CA, Ellebrecht CT, Obstfeld AE, Lacey SF, Melenhorst JJ, Nazimuddin F, Hwang WT, Maude SL, Wasik MA, Bagg A, Schuster S, Feldman MD, Porter DL, Grupp SA, June CH, Milone MC. Persistence of long-lived plasma cells and humoral immunity in individuals responding to CD19-directed CAR T-cell therapy. Blood 2016; 128(3): 360-370

100. Kansagra AJ, Frey NV, Bar M, Laetsch TW, Carpenter PA, Savani BN, Heslop HE, Bollard CM, Komanduri KV, Gastineau DA, Chabannon C, Perales MA, Hudecek M, Aljurf M, Andritsos L, Barrett JA, Bachanova V, Bonini C, Ghobadi A, Gill SI, Hill JA, Kenderian S, Kebriaei P, Nagler A, Maloney D, Liu HD, Shah NN, Kharfan-Dabaja MA, Shpall EJ, Mufti GJ, Johnston L, Jacoby E, Bazarbachi A, DiPersio JF, Pavletic SZ, Porter DL, Grupp SA, Sadelain M, Litzow MR, Mohty M, Hashmi SK. Clinical utilization of chimeric antigen receptor T-cells (CAR-T) in B-cell acute lymphoblastic leukemia (ALL) - an expert opinion from the European Society for Blood and Marrow Transplantation (EBMT) and the American Society for Blood and Marrow Transplantation (ASBMT). Bone Marrow Transplant 2019; 54(11): 1868-1880

101. Maude SL, Frey N, Shaw PA, Aplenc R, Barrett DM, Bunin NJ, Chew A, Gonzalez VE, Zheng Z, Lacey SF, Mahnke YD, Melenhorst JJ, Rheingold SR, Shen A, Teachey DT, Levine BL, June CH, Porter DL, Grupp SA. Chimeric antigen receptor T cells for sustained remissions in leukemia. N Engl J Med 2014; 371(16): $1507-1517$

102. Avigdor A, Shouval R, Jacoby E, Davidson T, Shimoni A, Besser $\mathrm{M}$, Nagler A. CAR T cells induce a complete response in refractory Burkitt lymphoma. Bone Marrow Transplant 2018; 53(12): 15831585

103. Wang ML, Munoz J, Goy A, Locke FL, Jacobson CA, Hill BT, Timmerman JM, Holmes H, Jaglowski S, Flinn IW, McSweeney PA, Miklos DB, Pagel JM, Kersten MJ, Peng W, Zheng L, Rossi JM, Jain RK, Rao AV, Reagan PM. KTE-X19, an anti-CD19 chimeric antigen receptor (CAR) $\mathrm{T}$ cell therapy, in patients (Pts) with relapsed/refractory (R/R) mantle cell lymphoma (MCL): results of the phase 2 ZUMA-2 study. Blood 2019; 134 (Supplement_1): 754

104. Liu E, Marin D, Banerjee P, Macapinlac HA, Thompson P, Basar R, Nassif Kerbauy L, Overman B, Thall P, Kaplan M, Nandivada V, Kaur I, Nunez Cortes A, Cao K, Daher M, Hosing C, Cohen EN,
Kebriaei P, Mehta R, Neelapu S, Nieto Y, Wang M, Wierda W, Keating M, Champlin R, Shpall EJ, Rezvani K. Use of CARtransduced natural killer cells in CD19-positive lymphoid tumors. N Engl J Med 2020; 382(6): 545-553

105. Cao J, Cheng H, Shi M, Wang G, Chen W, Qi K, Li H, Qiao J, Zhao J, Wu Q, Zeng L, Jing G, Zheng J, Xu K. Humanized CD19specific chimeric antigen-receptor T-cells in 2 adults with newly diagnosed B-cell acute lymphoblastic leukemia. Leukemia 2019; 33(11): 2751-2753

106. Ma G, Shen J, Pinz K, Wada M, Park J, Kim S, Togano T, Tse W. Targeting $\mathrm{T}$ cell malignancies using CD4CAR T-cells and implementing a natural safety switch. Stem Cell Rev Rep 2019; 15(3): 443-447

107. Gomes-Silva D, Srinivasan M, Sharma S, Lee CM, Wagner DL, Davis TH, Rouce RH, Bao G, Brenner MK, Mamonkin M. CD7edited $\mathrm{T}$ cells expressing a CD7-specific CAR for the therapy of Tcell malignancies. Blood 2017; 130(3): 285-296

108. Png YT, Vinanica N, Kamiya T, Shimasaki N, Coustan-Smith E, Campana D. Blockade of CD7 expression in T cells for effective chimeric antigen receptor targeting of T-cell malignancies. Blood Adv 2017; 1(25): 2348-2360

109. Byrne M, Oluwole OO, Savani B, Majhail NS, Hill BT, Locke FL. Understanding and managing large B cell lymphoma relapses after chimeric antigen receptor $\mathrm{T}$ cell therapy. Biol Blood Marrow Transplant 2019; 25(11): e344-e351

110. Walker AJ, Majzner RG, Zhang L, Wanhainen K, Long AH, Nguyen SM, Lopomo P, Vigny M, Fry TJ, Orentas RJ, Mackall CL. Tumor antigen and receptor densities regulate efficacy of a chimeric antigen receptor targeting anaplastic lymphoma kinase. Mol Ther 2017; 25(9): 2189-2201

111. Watanabe K, Terakura S, Martens AC, van Meerten T, Uchiyama S, Imai M, Sakemura R, Goto T, Hanajiri R, Imahashi N, Shimada K, Tomita A, Kiyoi H, Nishida T, Naoe T, Murata M. Target antigen density governs the efficacy of anti-CD20-CD28-CD3 chimeric antigen receptor-modified effector $\mathrm{CD} 8^{+} \mathrm{T}$ cells. J Immunol 2015; 194(3): 911-920

112. Caruso HG, Hurton LV, Najjar A, Rushworth D, Ang S, Olivares S, Mi T, Switzer K, Singh H, Huls H, Lee DA, Heimberger AB, Champlin RE, Cooper LJ. Tuning sensitivity of CAR to EGFR density limits recognition of normal tissue while maintaining potent antitumor activity. Cancer Res 2015; 75(17): 3505-3518

113. Turatti F, Figini M, Balladore E, Alberti P, Casalini P, Marks JD, Canevari S, Mezzanzanica D. Redirected activity of human antitumor chimeric immune receptors is governed by antigen and receptor expression levels and affinity of interaction. J Immunother 2007; 30(7): 684-693

114. Ying Z, Huang XF, Xiang X, Liu Y, Kang X, Song Y, Guo X, Liu H, Ding N, Zhang T, Duan P, Lin Y, Zheng W, Wang X, Lin N, Tu M, Xie Y, Zhang C, Liu W, Deng L, Gao S, Ping L, Wang X, Zhou N, Zhang J, Wang Y, Lin S, Mamuti M, Yu X, Fang L, Wang S, Song H, Wang G, Jones L, Zhu J, Chen SY. A safe and potent antiCD19 CAR T cell therapy. Nat Med 2019; 25(6): 947-953

115. Wang N, Hu X, Cao W, Li C, Xiao Y, Cao Y, Gu C, Zhang S, Chen L, Cheng J, Wang G, Zhou X, Zheng M, Mao X, Jiang L, Wang D, Wang Q, Lou Y, Cai H, Yan D, Zhang Y, Zhang T, Zhou J, Huang L. Efficacy and safety of CAR19/22 T-cell "Cocktail" therapy in patients with refractory/ relapsed B-cell malignancies. Blood 2020; 
135(1): 17- 27

116. Pan J, Zuo S, Deng B, Xu X, Li C, Zheng Q, Ling Z, Song W, Xu J, Duan J, Wang Z, Yu X, Chang AH, Feng X, Tong C. Sequential CD19-22 CAR T therapy induces sustained remission in children with r/r B-ALL. Blood 2020; 135(5): 387-391

117. Ruella M, Barrett DM, Kenderian SS, Shestova O, Hofmann TJ, Perazzelli J, Klichinsky M, Aikawa V, Nazimuddin F, Kozlowski M, Scholler J, Lacey SF, Melenhorst JJ, Morrissette JJ, Christian DA, Hunter CA, Kalos M, Porter DL, June CH, Grupp SA, Gill S. Dual CD19 and CD123 targeting prevents antigen-loss relapses after CD19-directed immunotherapies. J Clin Invest 2016; 126 (10): 3814-3826

118. Grada Z, Hegde M, Byrd T, Shaffer DR, Ghazi A, Brawley VS, Corder A, Schönfeld K, Koch J, Dotti G, Heslop HE, Gottschalk S, Wels WS, Baker ML, Ahmed N. TanCAR: a novel bispecific chimeric antigen receptor for cancer immunotherapy. Mol Ther Nucleic Acids 2013; 2: e105

119. Jia H, Wang Z, Wang Y, Liu Y, Dai H, Tong C, Guo Y, Guo B, Ti D, Han X, Yang Q, Wu Z, Han W. Haploidentical CD19/CD22 bispecific CAR- $T$ cells induced MRD-negative remission in a patient with relapsed and refractory adult B-ALL after haploidentical hematopoietic stem cell transplantation. J Hematol Oncol 2019; 12(1): 57

120. Zhao H, Hu Y, Nagler A, Chang AH, Huang H. CD19/CD22 dual targeted (chimeric antigen receptor) CAR-T therapy for relapsed or refractory (R/R) B-cell non-Hodgkin lymphoma (B-NHL). The 46th Annual Meeting of the EBMT. Abstract \#O038. 2020

121. Shah NN, Zhu F, Schneider D, Taylor C, Krueger W, Worden A, Longo WL, Hamadani M, Fenske T, Johnson B, Dropulic B, Orentas R, Hari P. Results of a phase I study of bispecific antiCD19, anti-CD20 chimeric antigen receptor (CAR) modified $T$ cells for relapsed, refractory, non-Hodgkin lymphoma. J Clin Oncol 2019; 37(15_suppl): 2510

122. Yan ZX, Li L, Wang W, OuYang BS, Cheng S, Wang L, Wu W, Xu PP, Muftuoglu M, Hao M, Yang S, Zhang MC, Zheng Z, Li J, Zhao WL. Clinical efficacy and tumor microenvironment influence in a dose-escalation study of anti-CD19 chimeric antigen receptor $\mathrm{T}$ cells in refractory B-cell non-Hodgkin's lymphoma. Clin Cancer Res 2019; 25(23): 6995-7003

123. Wherry EJ, Kurachi M. Molecular and cellular insights into T cell exhaustion. Nat Rev Immunol 2015; 15(8): 486-499

124. Zolov SN, Rietberg SP, Bonifant CL. Programmed cell death protein 1 activation preferentially inhibits CD28.CAR-T cells. Cytotherapy 2018; 20(10): 1259-1266

125. Wang H, Kaur G, Sankin AI, Chen F, Guan F, Zang X. Immune checkpoint blockade and CAR-T cell therapy in hematologic malignancies. J Hematol Oncol 2019; 12(1): 59
126. Chong EA, Melenhorst JJ, Lacey SF, Ambrose DE, Gonzalez V, Levine BL, June CH, Schuster SJ. PD-1 blockade modulates chimeric antigen receptor (CAR)-modified $\mathrm{T}$ cells: refueling the CAR. Blood 2017; 129(8): 1039-1041

127. Hill BT, Roberts ZJ, Xue A, Rossi JM, Smith MR. Rapid tumor regression from $\mathrm{PD}-1$ inhibition after anti-CD19 chimeric antigen receptor T-cell therapy in refractory diffuse large B-cell lymphoma. Bone Marrow Transplant 2020; 55(6): 1184-1187

128. Suarez ER, Chang K, Sun J, Sui J, Freeman GJ, Signoretti S, Zhu $\mathrm{Q}$, Marasco WA. Chimeric antigen receptor T cells secreting antiPD-L1 antibodies more effectively regress renal cell carcinoma in a humanized mouse model. Oncotarget 2016; 7(23): 34341-34355

129. Zhao W, Jia L, Zhang M, Huang X, Qian P, Tang Q, Zhu J, Feng Z. The killing effect of novel bi-specific Trop2/PD-L1 CAR-T cell targeted gastric cancer. Am J Cancer Res 2019; 9(8): 1846-1856

130. Garfall AL, Stadtmauer EA, Hwang WT, Lacey SF, Melenhorst JJ, Krevvata M, Carroll MP, Matsui WH, Wang Q, Dhodapkar MV, Dhodapkar K, Das R, Vogl DT, Weiss BM, Cohen AD, Mangan PA, Ayers EC, Nunez-Cruz S, Kulikovskaya I, Davis MM, Lamontagne A, Dengel K, Kerr ND, Young RM, Siegel DL, Levine BL, Milone MC, Maus MV, June CH. Anti-CD19 CAR T cells with high-dose melphalan and autologous stem cell transplantation for refractory multiple myeloma. JCI Insight 2018; 3(8): e120505

131. Sauter CS, Senechal B, Rivière I, Ni A, Bernal Y, Wang X, Purdon T, Hall M, Singh AN, Szenes VZ, Yoo S, Dogan A, Wang Y, Moskowitz CH, Giralt S, Matasar MJ, Perales MA, Curran KJ, Park J, Sadelain M, Brentjens RJ. CD19 CAR T cells following autologous transplantation in poor-risk relapsed and refractory Bcell non-Hodgkin lymphoma. Blood 2019; 134(7): 626-635

132. DeSelm C, Palomba ML, Yahalom J, Hamieh M, Eyquem J, Rajasekhar VK, Sadelain M. Low-dose radiation conditioning enables CAR T cells to mitigate antigen escape. Mol Ther 2018; 26 (11): 2542-2552

133. Sim AJ, Jain MD, Figura NB, Chavez JC, Shah BD, Khimani F, Lazaryan A, Krivenko G, Davila ML, Liu HD, Falchook AD, Dahiya S, Rapoport AP, Kim S, Locke FL, Robinson TJ. Radiation therapy as a bridging strategy for CAR $\mathrm{T}$ cell therapy with axicabtagene ciloleucel in diffuse large B-cell lymphoma. Int $\mathrm{J}$ Radiat Oncol Biol Phys 2019; 105(5): 1012-1021

134. Mestermann K, Giavridis T, Weber J, Rydzek J, Frenz S, Nerreter T, Mades A, Sadelain M, Einsele H, Hudecek M. The tyrosine kinase inhibitor dasatinib acts as a pharmacologic on/off switch for CAR T cells. Sci Transl Med 2019; 11(499): eaau5907

135. Weber EW, Lynn RC, Sotillo E, Lattin J, Xu P, Mackall CL. Pharmacologic control of CAR-T cell function using dasatinib. Blood Adv 2019; 3(5): 711-717 